Brit. F. industr. Med., 1968, 25, 203.

\title{
Distribution and Excretion of Triethyllead in Rats
}

\author{
WANDA BOLANOWSKA
}

From the Laboratory for the Metabolism of Toxic Substances, Institute of Occupational Medicine, Lódz, Poland

The distribution and excretion of triethyllead and inorganic lead in rats have been studied after the intravenous administration of tetraethyllead, using a new method for separating triethyllead. Tetraethyllead was rapidly converted to triethyllead. The highest levels of triethyllead were found in the liver, blood, kidney, and brain. Twenty-four hours after the administration of tetraethyllead $50 \%$ of the total lead in the soft organs was in the form of triethyllead. Triethyllead concentration in vivo then remained steady for several days. Triethyllead was excreted in the faeces and urine at a rate equivalent to not more than $1 \%$ daily of the dose of tetraethyllead. Inorganic lead constituted the remainder of the lead in vivo from 24 hours after injection. Diethyllead was not found even shortly after administration of tetraethyllead. Diethyllead was fairly stable in vivo but less so than triethyllead. The metabolism of tetraethyllead takes place in two independent ways: one to the comparatively stable triethyllead ion, which is responsible for the toxic effects of tetraethyllead, and the other directly to inorganic lead.

Most of the previous work on the metabolism of tetraethyllead has been published by Cremer (1959); and by Cremer and Callaway (196I). She showed that the main product was the triethyllead ion $\left(\mathrm{Et}_{3} \mathrm{~Pb}^{+}\right)$, which is responsible for the toxic effects of tetraethyllead, and which was found in particularly high concentrations in the liver, blood, kidneys, and brain.

In experiments on liver and brain homogenates Cremer (1959) also showed that the enzymatic system which converts tetraethyllead into triethyllead is found only in the liver. The toxic action of the other possible metabolites, diethyllead $\left(\mathrm{Et}_{2} \mathrm{~Pb}^{++}\right)$and ionic lead $\left(\mathrm{Pb}^{++}\right)$, differs from that of triethyllead and does not involve changes in brain metabolism. The usual antidotes to heavy metal poisoning, EDTA and BAL, are of no help in cases of poisoning with tetraethyllead; and there is no information about any effective methods of diagnosis and treatment.

\section{Methods}

Animals Male and female rats, of 170 to $250 \mathrm{~g}$. body weight, were used. For the excretion studies they were kept in Simax metabolism cages, enabling separate collection of urine and faeces.

Lead Compounds Tetraethyllead was obtained by

Received for publication June 7, 1967. distilling the technical product at reduced pressure in red light (b.p. $88^{\circ} \mathrm{C}$. $/ 18 \mathrm{~mm}$.).

Triethyllead and diethyllead chloride were synthesized as described by Heap, Saunders, and Stacey (1949; 195 I).

The products contained no free lead (sulphide test, Heap et al., 1951). Lead was estimated as the chromate after digestion (Saunders and Stacey, 1949) and was $96-98 \%$ of the theoretical value. Chloride was estimated as silver chloride (Struszyński, 1949) and was 98-100\% of the theoretical value.

All compounds were stored at $-18^{\circ} \mathrm{C}$. in the dark.

Solutions for Injection Tetrathyllead was given intravenously in ethanol. Each rat received $0.1-0.15 \mathrm{ml}$.

Triethyllead chloride and diethyllead dichloride were given in water $(0.3-0.5 \mathrm{ml}$.).

Estimation of Lead in Biological Materials The methods allowed separate estimation of triethyllead, total lead, and of precipitable and unprecipitable lead. The final stages were the same in all four cases. The specimens were digested by heating with concentrated sulphuric and nitric acid, and lead was estimated in the products by the one-coloured dithizone method, as adapted by Dutkiewicz, Piotrowski, and KȩsyDąbrowska (1964). The lead was extracted from aqueous medium, $p \mathrm{H} 9.5$, with dithizone in chloroform in the presence of sodium citrate, hydroxylamine hydrochloride, and potassium cyanide. Excess dithizone was removed by shaking with dilute ammonia-potassium cyanide solution. The lead-dithizone complex was estimated using a KF-3 absorptiometer in $20-\mathrm{mm}$. cuvettes with a green filter. The sensitivity was $2 \mu \mathrm{g}$, , and the precision in the range of $2-20 \mu \mathrm{g}$. was $6 \%$. 
Principles of Separation of Ethylleads and Inorganic Lead The methods (Bolanowska, 1967) depend on two processes-the separation of tetraethyllead from triethyllead and both from diethyllead and lead ions by distribution between benzene and water. Diethyllead was separated from lead ions by the precipitation of the latter as lead oxalate.

Tetraethyllead is extracted quantitatively by benzene from aqueous media, including homogenates of tissues. Diethyllead and lead ions cannot be extracted by benzene. Triethyllead ions $\left(\mathrm{Et}_{3} \mathrm{~Pb}^{+}\right)$cannot be extracted, but undissociated triethyllead chloride $\left(\mathrm{Et}_{3} \mathrm{PbCl}\right)$ is readily extracted. The dissociation can be suppressed with sodium chloride $(\mathrm{NaCl})$. Consequently, in the $p H$ range 5 to ro the distribution coefficient, benzene/aqueous phase, varies from 0.01 when the aqueous phase is water to about 100 when it is $300 \mathrm{mg}$. $\mathrm{NaCl} / \mathrm{ml}$. (Fig. I). At

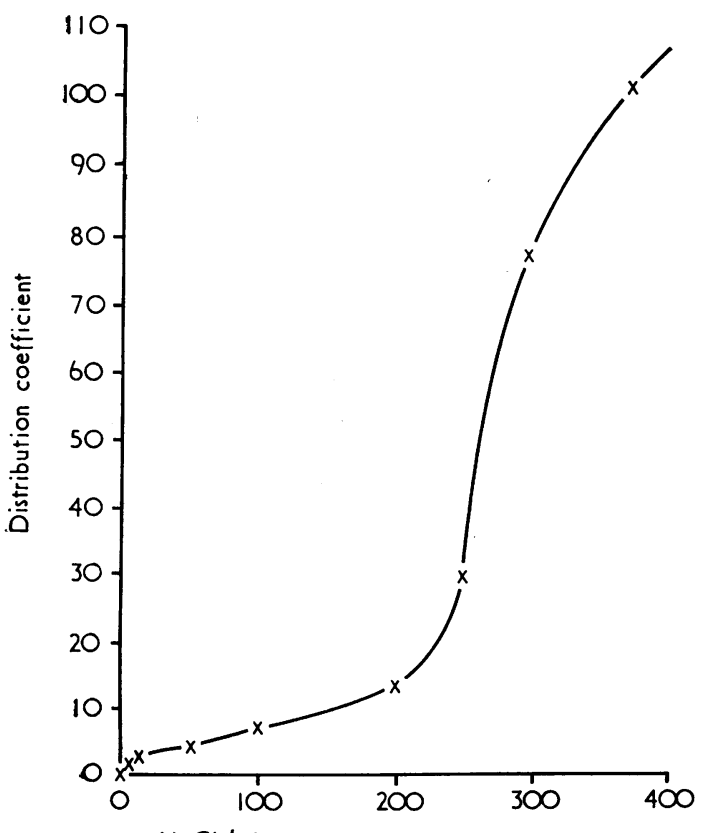

mg. $\mathrm{NaCl} / \mathrm{ml}$.

Fig. I. Variation of the distribution coefficient of triethyllead in the system: benzene/aqueous $\mathrm{NaCl}$ with $\mathrm{NaCl}$ concentration.

lower $p H s$ the coefficient is lower but still high, 30-50 from $300 \mathrm{mg}$. $\mathrm{NaCl} / \mathrm{ml}$. Thus from $\mathrm{NaCl}$ solution tetraethyllead and triethyllead can be separated from diethyllead and lead ions; and by back-extraction with water the triethyllead can be separated in turn from the tetraethyl lead.

Detailed Method Tissue (I g.) or the faeces or urine collected over 24 hours was suspended in $50 \mathrm{ml}$. water, and $15 \mathrm{~g}$. $\mathrm{NaCl}$ were added. The mixture was shaken with benzene $(25 \mathrm{ml}$.) and centrifuged, and the benzene layer was separated. The triethyllead was back-extracted with $20-\mathrm{ml}$. portions of $\mathrm{r} \%$ nitric acid and estimated as lead in the way already described. Recoveries were 90-100\%.

Inorganic lead was estimated as follows. Tissue ( 1 g.) was homogenized in water (10 ml.) and protein was precipitated with ro $\mathrm{ml}$. of $30 \%$ perchloric acid (w/v). About $10 \%$ of the lead was lost on the protein. After centrifugation the supernatant was separated and its $p H$ was adjusted to 4.5 with I N NaOH (bromocresol green indicator), and its volume was made up to $100 \mathrm{ml}$. with water. Saturated ammonium oxalate $(5 \mathrm{ml}$.) and 10\% calcium chloride $(0.5 \mathrm{ml}$.) were added, and the mixture was left overnight. The precipitate of lead oxalate which separated was analysed for lead in the normal way and gave the inorganic lead content of the tissues. The lead in the supernatant was also estimated and gave the organic lead content.

\section{Tests of Specificity}

Triethyllead The method was carried out in triplicate on roo $\mu \mathrm{g}$. each of lead nitrate, lead-EDTA complex, diethyllead chloride and tetraethyllead in water, and diethyllead chloride in urine and blood. Recoveries of lead were never more than equivalent to I $\mu \mathrm{g}$. of triethyllead.

To exclude the possibility that in vivo inorganic lead may form compounds analysing as triethyllead, a rat was given $20 \mathrm{mg}$. $\mathrm{Pb} / \mathrm{kg}$. intravenously as lead nitrate solution in acetate buffer, $p \mathrm{H} 5 \cdot 2$. It was killed two days later. No material studied contained anything analysing as triethyllead, although the total lead content was high (Table I).

\section{TABLE I}

SPECIFICITY OF METHOD FOR TRIETHYLLEAD IN THE Presence of Some Lead Compounds in the Rat after INTRAVENOUS INJECTION OF LEAD Nitrate

\begin{tabular}{|c|c|c|c|c|c|}
\hline \multicolumn{4}{|c|}{ Material Analysed } & \multirow{2}{*}{$\begin{array}{c}\begin{array}{c}\text { Total Lead } \\
(\mu g \cdot / g .)\end{array} \\
47 \cdot 0\end{array}$} & \multirow{2}{*}{$\frac{\begin{array}{c}\text { Triethyllead' } \\
(\mu g \cdot / g .)\end{array}}{\circ}$} \\
\hline Liver & $\ldots$ & $\ldots$ & $\ldots$ & & \\
\hline Kidney & . & . & $\ldots$ & $31 \cdot 0$ & 0 \\
\hline Blood & $\ldots$ & .. & $\ldots$ & 0.6 & 0 \\
\hline Urine & $\ldots$ & . & $\ldots$ & $I \cdot 5$ & 0 \\
\hline Faeces & . & . & $\cdots$ & $45^{\circ} 0$ & 0 \\
\hline
\end{tabular}

Precipitable Lead The procedure for estimating inorganic (precipitable) lead was carried out on the whole bodies of rats given lead nitrate, diethyllead chloride or tetraethyllead, or on homogenates of whole bodies to which diethyl- or triethyl-lead chloride were added. Table II shows that after injection of inorganic lead (nitrate) nearly all the lead was precipitable, whereas in in vitro tests very little lead added as diethyl- or triethyl-lead chloride was precipitated. The procedure was thus nearly specific for inorganic lead. 
TABLE II

Precipitable and Unprecipitable Lead Compounds in the Whole Bodies of Rats after Intravenous Administration (in vivo) OR ADDITION TO HOMOgENATEs (in vitro) OF VARIOUS LEAD CoMPOUNDS

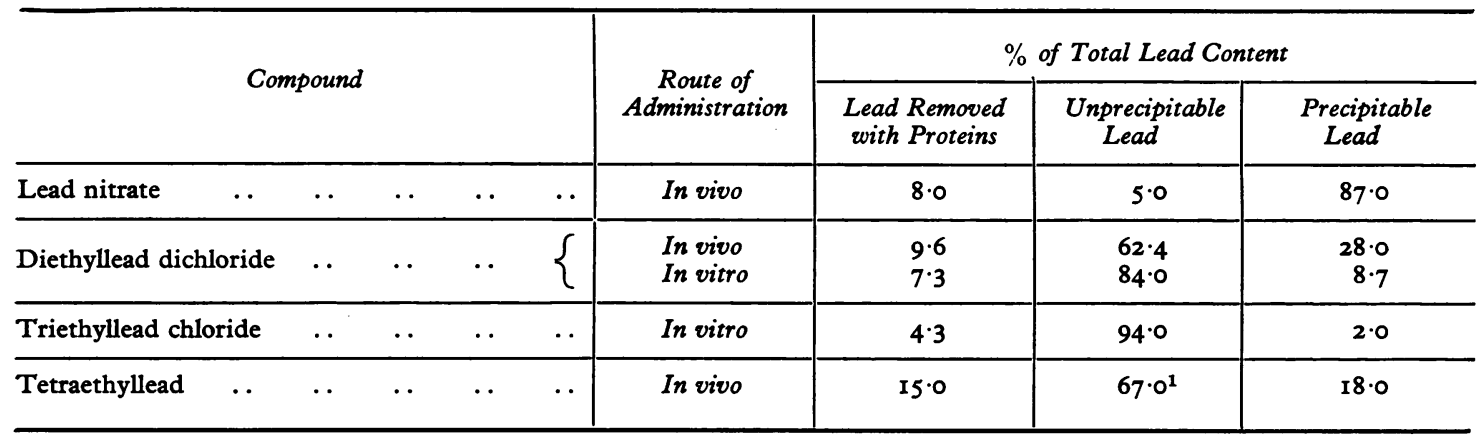

${ }^{1}$ Simultaneous determination of triethyllead gave a value of $71 \%$ of total lead content.

\section{Results}

Nature of Metabolites Rats were given $31 \mu$ moles tetraethyllead $/ \mathrm{kg}$. and killed 24 hours later and their bodies, less skin and tails, were homogenized. It was found that $18 \%$ of the lead was precipitable, i.e., inorganic, and $67 \%$ was unprecipitable, i.e., organic. The rest was precipitated with proteins (Table II). In parallel estimations, triethyllead accounted for $71 \%$ of the total lead, very close to the total organic lead. Thus by 24 hours very little tetraethyllead remained, and all the lead could be accounted for by triethyllead and inorganic lead. There was thus little or no diethyllead.

Distribution and Excretion of Triethyllead Preliminary investigations confirmed Cremer's statement that triethyllead is the main metabolite and that its highest concentrations are in the liver, blood, kidney, and brain (Cremer, 1959; Cremer and Callaway, 196I). In further experiments, therefore, triethyllead was usually estimated only in these organs. In a few cases it was also estimated in muscle.

Triethyllead concentrations in blood were proportional to the dose of tetraethyllead over a fourfold range 24 hours after injection (Table III).

The dynamics of triethyllead retention and excretion were investigated after a dose of $3 \mathbf{I}$ $\mu$ moles $\mathrm{Et}_{4} \mathrm{~Pb} / \mathrm{kg}$. The results (Fig. 2) showed considerable variations, but the main features are clear. Only in blood did the triethyllead concentration fall in the first few days. Triethyllead was excreted both in faeces and in urine (Fig. 3), but the rate never exceeded $I \%$ of the dose per day. After the first day excretion was mainly in the faeces.
TABLE III

LeVELS OF TriethylLEAD IN BLOOD 24 Hours AFTER INTRAVENOUS INJECTION OF TETRAETHYLLEAD

\begin{tabular}{c|c|c}
\hline $\begin{array}{c}\text { Dose } \\
(\mu \text { moles/kg. })\end{array}$ & $\begin{array}{c}\text { No. of } \\
\text { Rats }\end{array}$ & $\begin{array}{c}\text { Triethyllead Found } \\
(\mu \text { moles/g. of blood } \pm \text { S.D. })\end{array}$ \\
\hline 15.5 & 3 & $0.032 \pm 0.0068$ \\
31.0 & 7 & $0.050 \pm 0.0190$ \\
62.0 & 6 & $0.086 \pm 0.0210$ \\
\hline
\end{tabular}

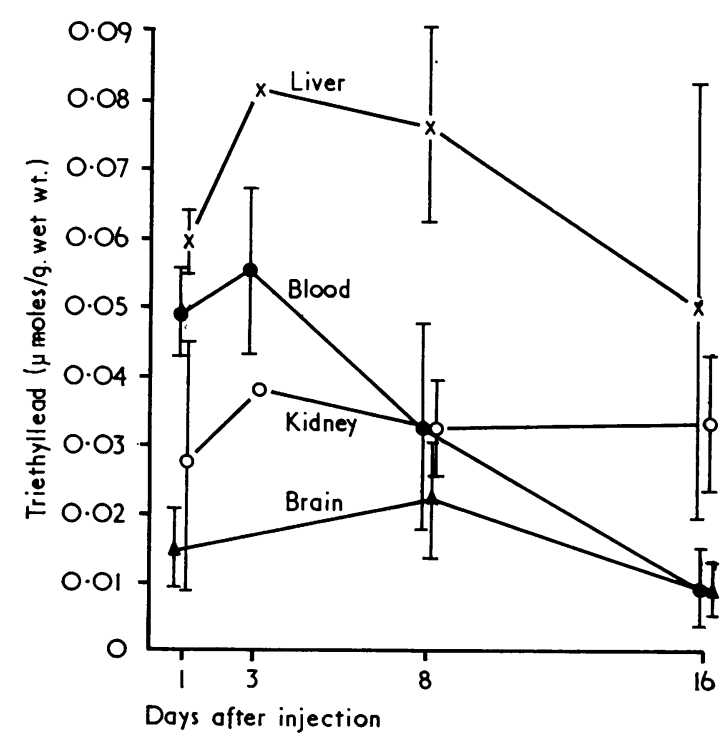

FIG. 2. Concentrations (mean \pm S.D.) of triethyllead in tissues after injection of ${ }_{31} \mu$ moles $\mathrm{Et}_{\mathbf{4}} \mathrm{Pb} / \mathrm{kg}$. 


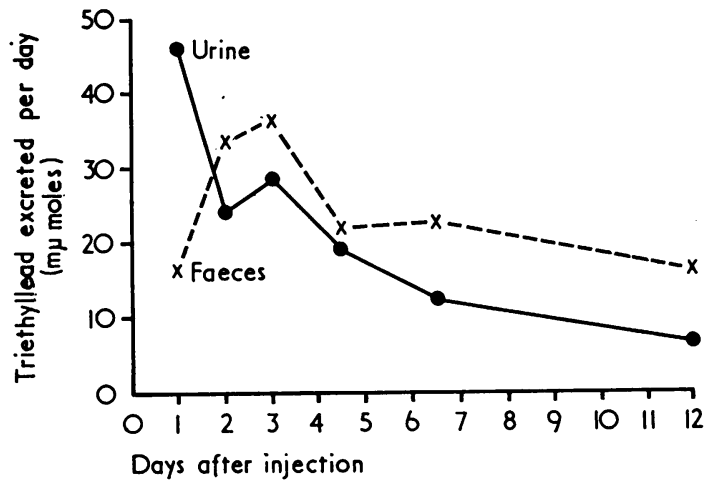

FIG. 3. Excretion of triethyllead in urine and faeces after injection of $31 \mu$ moles $\mathrm{Et}_{4} \mathrm{~Pb} / \mathrm{kg}$.

Triethyllead and Total Lead To assess the share of triethyllead in the metabolites further experiments were carried out on two groups of rats: one of them received $62 \mu$ moles $\mathrm{Et}_{4} \mathrm{~Pb} / \mathrm{kg}$. body weight and the rats were killed after 24 hours. The other received $3 \mathrm{I} \mu$ moles $\mathrm{Et}_{4} \mathrm{~Pb} / \mathrm{kg}$. body weight and the rats were killed after 7 days. In both groups triethyllead and total lead were determined.

The results are shown in Tables IV and V. Twenty-four hours after administration triethyllead in the internal organs amounted to only $50 \%$ and in muscles to $70 \%$ of the total lead content. Seven days after administration of tetraethyllead, however, almost all the lead in the internal organs was found in the form of triethyllead.

\section{TABLE IV}

Tissue Levels of Triethyllead and Total Lead 24 Hours after INJECTION OF TETRAeTHyLLEAD IN A Dose OF $62 \mu$ MOLES/Kg. BODY WeIGHT (MEAN \pm STANDARD Deviation)

\begin{tabular}{l|c|cc}
\hline Tissues & $\begin{array}{c}\text { No. of } \\
\text { of Rats }\end{array}$ & $\begin{array}{c}\text { Triethyllead } \\
(\mu \text { moles/g. wet wt. })\end{array}$ \\
\hline Blood & 5 & $\begin{array}{r}0.085 \\
\pm 0.023\end{array}$ & $\begin{array}{r}0.174 \\
\pm 0.031\end{array}$ \\
\hline Liver & 6 & $\begin{array}{r}0.065 \\
\pm 0.008\end{array}$ & $\begin{array}{r}0.147 \\
\pm 0.020\end{array}$ \\
\hline Kidney & 4 & $\begin{array}{r}0.056 \\
\pm 0.017\end{array}$ & $\begin{array}{r}0.128 \\
\pm 0.041\end{array}$ \\
\hline Brain & 6 & $\begin{array}{r}0.045 \\
\pm 0.021\end{array}$ & - \\
\hline Muscles & 6 & $\begin{array}{r}0.015 \\
\pm 0.005\end{array}$ & $\begin{array}{r}0.021 \\
\pm 0.009\end{array}$ \\
\hline
\end{tabular}

TABLE V

Tissue Levels of Triethyllead and Total Lead 7 Days after INJECTION OF Tetraethyllead IN A Dosz OF $31 \mu$ MOLES/KG. BODY WEIGHT (Mean \pm Standard Deviation)

\begin{tabular}{|c|c|c|c|}
\hline Tissues & $\begin{array}{l}\text { No. of } \\
\text { Rats }\end{array}$ & \multicolumn{2}{|c|}{$\begin{array}{c}\text { Triethyllead Total Lead } \\
(\mu \text { moles/g. wet wt. })\end{array}$} \\
\hline Blood & 5 & $\begin{array}{r}0.036 \\
\pm 0.022\end{array}$ & $\begin{array}{r}0.036 \\
\pm 0.018\end{array}$ \\
\hline Liver & 4 & $\begin{array}{r}0.080 \\
\pm 0.014\end{array}$ & $\begin{array}{r}0.078 \\
\pm 0.009\end{array}$ \\
\hline Kidney & 4 & $\begin{array}{r}0.033 \\
\pm 0.008\end{array}$ & $\begin{array}{r}0.041 \\
\pm 0.006\end{array}$ \\
\hline Brain & 4 & $\begin{array}{r}0.025 \\
\pm 0.008\end{array}$ & $\begin{array}{r}0.028 \\
\pm 0.010\end{array}$ \\
\hline Muscles & 4 & $\begin{array}{r}0.017 \\
\pm 0.004\end{array}$ & $\begin{array}{r}0.020 \\
\pm 0.007\end{array}$ \\
\hline
\end{tabular}

Metabolism of Diethyllead The apparent absence of diethyllead from the metabolites of tetraethyllead could have been due either to a rapid degradation of diethyllead to ionic lead or to its not being formed. To decide between these explanations five rats were given diethyllead dichloride $(48 \cdot 3$ $\mu$ moles $/ \mathrm{kg}$.) intravenously and killed after 24 hours. In 'whole-body' homogenates the precipitable and unprecipitable lead were estimated. Unprecipitable lead, i.e., in this case unchanged diethyllead, accounted for $62 \%$ of the total lead. Thus, although diethyllead was somewhat less stable in vivo than triethyllead, its rate of conversion was not high enough to account for its absence from rats shortly after the administration of tetraethyllead.

In other experiments excretion of lead in urine was followed for three days. During the first day $80 \%$ of the lead was unprecipitable, but by three days only $50 \%$ was unprecipitable (Fig. 4), i.e., at first the excretion of unchanged diethyllead predominated but afterwards as it was metabolized the elimination of ionic lead became more important. The excretion of precipitable lead in the urine of rats given lead nitrate intravenously has been shown on the same figure for comparison. In this case practically all the lead was precipitable.

Metabolism of Triethyllead As already shown, triethyllead formed in vivo from tetraethyllead was very stable. To see whether triethyllead given intravenously behaved similarly, $30.4 \mu$ moles triethyllead chloride $/ \mathrm{kg}$. were given, and faeces and urine were collected during a week. Rats were killed 


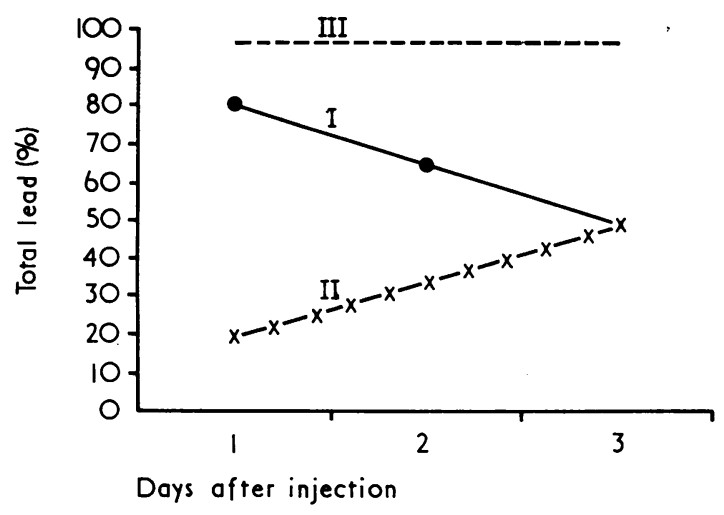

FIG. 4. Percentages of total lead in urine after injection of diethyllead chloride as unprecipitable lead (I) and precipitable lead (II). For comparison, precipitable lead after injection of lead nitrate is shown (III).

at various time intervals after administration, and analyses were carried out on whole-body homogenates and on the excreta. In faeces only triethyllead was determined. Table VI shows that triethyllead was stable in vivo for a week. The concentrations were close to those administered. The excretion of triethyllead (Table VII) in this experiment was twice as fast as after the administration of an equal dose of tetraethyllead (Fig. 3), probably because only part of the tetraethyllead was converted to triethyllead.

\section{Discussion}

It is known that under the influence of various physical and chemical agents tetraethyllead is
TABLE VI

Triethyllead and Total Lead in Homogenized WHOLE BODIES OF RATS AFTER INTRAVENOUS INJECTION of Triethyllead Chloride in a Dose of $30.4 \mu$ MOles/ KG. BODY Weight (Mgan \pm Standard Deviation or INDIVIDUAL RESULTS WHEN $\mathbf{n}=2$ )

\begin{tabular}{|c|c|c|c|}
\hline $\begin{array}{l}\text { Time } \\
\text { Killed after } \\
\text { Injection }\end{array}$ & $\begin{array}{c}\text { No. of } \\
\text { Rats }\end{array}$ & \multicolumn{2}{|c|}{$\begin{array}{c}\text { Triethyllead } \\
(\mu \text { moles } / \mathrm{g} .)\end{array}$} \\
\hline $\mathbf{I}$ & 5 & $\begin{array}{r}0.033 \\
\pm 0.003\end{array}$ & $\begin{array}{r}0.037 \\
\pm 0.007\end{array}$ \\
\hline 3 & 2 & $0.023 \quad 0.024$ & $0.029 \quad 0.032$ \\
\hline 4 & 4 & $\begin{array}{c}0.031 \\
\pm 0.008\end{array}$ & $\begin{array}{r}0.030 \\
\pm 0.002\end{array}$ \\
\hline 6 & 2 & $0.017 \quad 0.030$ & $0.022 \quad 0.036$ \\
\hline 7 & 2 & $0.024 \quad 0.026$ & $0.024 \quad 0.026$ \\
\hline
\end{tabular}

degraded via triethyl- and diethyl-lead to inorganic lead (Calingaert, Shapiro, Dykstra, and Hess, I948; Henderson and Snyder, 1961).

$$
\mathrm{Et}_{4} \mathrm{~Pb} \longrightarrow \mathrm{Et}_{3} \mathrm{~Pb}^{+} \longrightarrow \mathrm{Et}_{2} \mathrm{~Pb}^{++} \longrightarrow \mathrm{Pb}^{++}
$$

Cremer (1959) found high levels of triethyllead in rat tissues 24 hours after the administration of tetraethyllead, and these levels did not change significantly during the next four days. From this she concluded that the first stage of degradation took place very quickly in vivo, while the subsequent stages to diethyllead and ionic lead were much slower. There was, however, no evidence of the last stage in vivo (Cremer, 1965).

TABLE VII

Excretion of Triethyllead and Total Lead after Intravenous Injection of Triethyllead ChLoride in a Dose

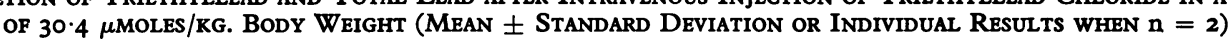

\begin{tabular}{|c|c|c|c|c|c|}
\hline \multirow{2}{*}{$\begin{array}{c}\text { Time after } \\
\text { Injection (days) }\end{array}$} & \multicolumn{3}{|c|}{ Urine } & \multicolumn{2}{|c|}{ Faeces } \\
\hline & $\begin{array}{l}\text { No. of } \\
\text { Rats }\end{array}$ & Triethyllead & Total Lead & $\begin{array}{l}\text { No. of } \\
\text { Rats }\end{array}$ & $\begin{array}{c}\text { Triethyllead } \\
\text { ( } \mu \text { moles/day) }\end{array}$ \\
\hline $\mathbf{I}$ & 8 & $\begin{array}{r}0.090 \\
\pm 0.029\end{array}$ & $\begin{array}{r}0.104 \\
\pm 0.030\end{array}$ & 2 & $0.014 \quad 0.019$ \\
\hline 2 & 6 & $\begin{array}{r}0.078 \\
\pm 0.021\end{array}$ & $\begin{array}{r}0.090 \\
\pm 0.035\end{array}$ & 6 & $\begin{array}{r}0.020 \\
\pm 0.011\end{array}$ \\
\hline $3-4$ & 3 & $\begin{array}{r}0.058 \\
\pm 0.008\end{array}$ & $\begin{array}{r}0.084 \\
\pm 0.019\end{array}$ & 2 & $0.007 \quad 0.011$ \\
\hline $5-7$ & 2 & $0.035 \quad 0.058$ & 0.0730 .101$. & 2 & $0.024 \quad 0.034$ \\
\hline
\end{tabular}


The present work indicates that the metabolism of tetraethyllead involves simultaneous conversion to triethyllead and to inorganic lead:

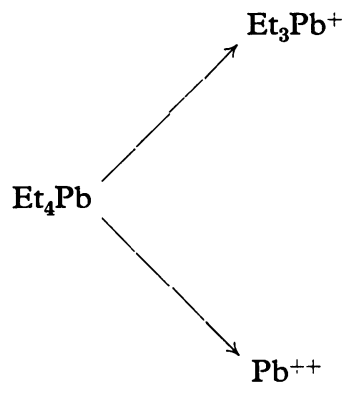

Conversion of tetraethyllead to triethyllead was fast, and by 24 hours triethyllead constituted $40-50 \%$ of the total lead found in internal organs and $70 \%$ of that in muscle. Thereafter the triethyllead content of the rat did not alter significantly for several days. Precipitable, i.e., inorganic, lead was also produced rapidly but mostly disappeared within a week. The indirect method used for the estimation of diethyllead did not show any diethyllead to be present in rats given tetraethyllead.

As diethyllead given to rats was not metabolized rapidly, it is unlikely that it was an intermediate metabolite. It is, therefore, probable that triethyllead and inorganic lead were the only metabolites of tetraethyllead. It is known that inorganic lead is excreted and deposited in bones fairly quickly, which explains why by seven days only triethyllead could be found in the soft organs of the body.

Metabolism of tetraethyllead, then, takes place in two independent ways - to triethyllead and to inorganic lead. The triethyllead determines the characteristic toxic effect of tetraethyllead. The biological effects of inorganic lead are quite different.

The presence of almost constant levels of triethyllead in rats for a week indicates the possibility of its accumulation during chronic exposure to tetraethyllead. This is of great practical importance, since the presence of triethyllead has also been demonstrated in human cases who died up to 20 days after acute poisoning with tetraethyllead (Bolanowska, Piotrowski, and Garczyński, 1967).

The author wishes to thank Dr. J. Piotrowski for valuable help and discussion. The technical assistance of Miss J. Jerszyńska is greatly appreciated.

\section{REFERENCES}

Bolanowska, W. (1967). A method of determination of triethyllead in blood and urine (in Polish). Chemia analit., 12, 12 I-129.

—, Piotrowski, J., and Garczyński, H. (1967). Triethyllead in the biological material in cases of acute tetraethyllead poisoning. Arch. Toxikol., 22, 278-282.

Calingaert, G., Shapiro, H., Dykstra, F. J., and Hess, L. (I948). The decomposition of alkyllead compounds. f. Amer. chem. Soc., 70, 3902-3906.

Cremer, J. E. (1959). Biochemical studies on the toxicity of tetraethyl lead and other organo-lead compounds. Brit. F. industr. Med., 16, 191-199.

- (1965). Toxicology and biochemistry of alkyl lead compounds. Occup. Hlth Rev., 17, No. 3, pp. 14-19.

- , and Callaway, S. (I96I). Further studies on the toxicity of some tetra and trialkyl lead compounds. Brit. $\mathcal{F}$. industr. Med., 18, 277-282.

Dutkiewicz, T., Piotrowski, J., and Kesy-Dabrowska, I. (1964). Chemical Analysis of the Biological Material in Industrial Toxicology (in Polish). PZWL, Warsaw.

Heap, R., Saunders, B. C., and Stacey, G. J. (1949). Organolead compounds. Part II. F. chem. Soc., pp. 2983-2988.

$\longrightarrow,-$, and - (195I). Organo-lead compounds. Part IV. Ibid., pp. 658-664.

Henderson, S. R., and Snyder, L. J. (I96r). Rapid spectrophotometric determination of triethyllead, diethyllead, and inorganic lead ions, and application to the determination of tetraorganolead compounds. Anal. Chem., 33, II72-II75:

Saunders, B. C., and Stacey, G. J. (1949). Organo-lead compounds. Part I. f. Chem. Soc., 919-925.

Struszyński, M. (1949). Quantitative and Technical Analysis (in Polish). Warsaw. 